\title{
The development of growth centres and hinterland areas in Bangka Regency, Indonesia
}

Sella Agustina ${ }^{1 *}$, Devi Valeriani ${ }^{2}$, Anggraeni Yunita ${ }^{3}$

Faculty of Economics, University of Bangka Belitung, Bangka, Indonesia ${ }^{1,2,3}$

sellaagustina4@gmail.com ${ }^{1}$,deviyono92@gmail.com ${ }^{2}$, anggi21.ay@gmail.com ${ }^{3}$

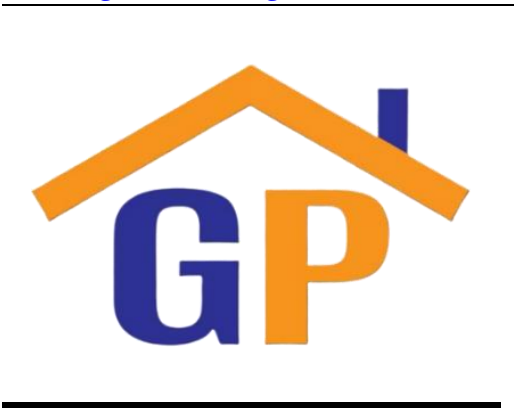

Article History

Received on 19 July 2021

$1^{\text {st }}$ Revision on 19 August 2021

$2^{\text {nd }}$ Revision on 23 August 2021

Accepted on 25 August 2021

\author{
Abstract \\ Purpose: This study aims to determine and analyze the \\ development of growth centers and hinterland areas in Bangka \\ Regency, Indonesia.
}

Research Methodology: The analytical methods used are scalogram analysis, centrality index, gravity analysis, and GIS (Geographic Information System) methods. The type of data is quantitative data. The data source is secondarily obtained from BPS of Bangka Regency.

Results: The results of the scalogram analysis and centrality index showed that Sungailiat District had the first order as the center of growth. The other seven districts, namely Belinyu, Merawang, Mendo Barat, Pemali, Riau Silip, Puding Besar, and Bakam are hinterland areas. Sungailiat District as the growth center has the strongest interaction value with the hinterland area, namely Pemali District, and the weakest interaction value with Bakam District.

Limitations: This research uses the descriptive quantitative approach in its calculations using simple mathematical calculations. Further research is needed to find out how much influence it has on the region.

Contributions: This study is to provide alternative inputs to the government of the Bangka Regency in formulating policy planning and decision-making regarding growth centers and hinterland areas.

Keywords: Centrality Index, GIS, Gravity, Growth Center, Hinterland, Scalogram

How to cite: Agustina, S., Valeriani, D., \& Yunita, A. (2021). The development of growth centers and hinterland areas in Bangka Regency, Indonesia Journal of Social, Humanity, and Education, 2(1), 1-17.

\section{Introduction}

Development planning is a process related to decisions or choices of various alternatives in using existing resources to achieve certain goals in the future (Arsyad, 2018). Development planning needs to involve the community both directly and indirectly, and in regional development planning, an agreement is needed between the government and the community. Regional development planning is planning for the use and activities of regional space that can be used by the community in one place. There are two approaches to regional development planning, namely the sectoral approach and the regional approach. A sectoral approach is an approach in which all regional economic activities are grouped into each commodity sector. Each sector is further divided into commodity sub-sectors that have their respective potentials and opportunities. Meanwhile, the regional approach is a spatial or regional approach related to development planning with spatial plans (Tarigan, 2019).

The regional approach requires the concentration of facilities efficiently in addition to paying attention to the use of space for the production of goods or services. A very important factor to consider in development planning is the population. The population is the main factor in determining the amount of demand for consumption materials that need to be provided as well as the number of public facilities that need to be built in an area (Tarigan, 2019). According to Smith, economic 
development is a process in which population growth and technological progress must be balanced, so that economic specialization will occur if population growth is balanced with rapid technological advances (Sukirno, 2011; Rochaida, 2016).

An area has a supporting area, namely the surrounding area or hinterland. Hinterland is a back or supporting area whose function is as an area to provide food or basic needs for other areas and the community can take advantage of the facilities at the growth center (Ismiwati \& Sayuti, 2019). The existence of a decentralization policy makes regional development achievable by increasing regional potential and increasing inadequate facilities. Policies taken by local governments aim to increase development and equitable development to other regions (Nandya, 2016).

One solution to increase development is to establish a growth center in the region. The growth center can cause a positive spillover effect in the supporting area or hinterland. Equitable distribution of facilities is owned by growth centers, such as schools, hospitals, health centers, banks, places of worship, and other social facilities. The implication is that the existing facilities do not only serve the population of the growth center area but also serve residents who come from outside the city or area called the hinterland area or supporting area (Utari, 2015; Ismiwati \& Sayuti, 2019).

Seeing these potentials, problems, and challenges, the role of national and regional development planning becomes very important. It is necessary to formulate a development plan to achieve fair and equitable development by increasing regional development, reducing overall social inequality by increasing support for the community, especially for groups and regions/villages that are still lagging, overcoming poverty and unemployment, and providing equal access to the community with various social services and economic facilities and infrastructure as well as eliminating discrimination in all aspects including gender (Kuncoro, 2018).

The government's policy to develop the region is to establish certain areas as growth centers (growth poles). The growth center (service) is one way to mobilize and encourage development to increase people's income. If economic growth is in an area that has regional potential and facilities, then economic development will be accelerated because regional progress will indirectly direct people to seek a more decent life in their region (Ardila, 2012; Imelda, 2013; Gulo, 2015).

The development of the population by regency/city in the Province of Bangka Belitung Islands shows an increasing development. The following is a picture of the population by regency/city in the Province of Bangka Belitung Islands.

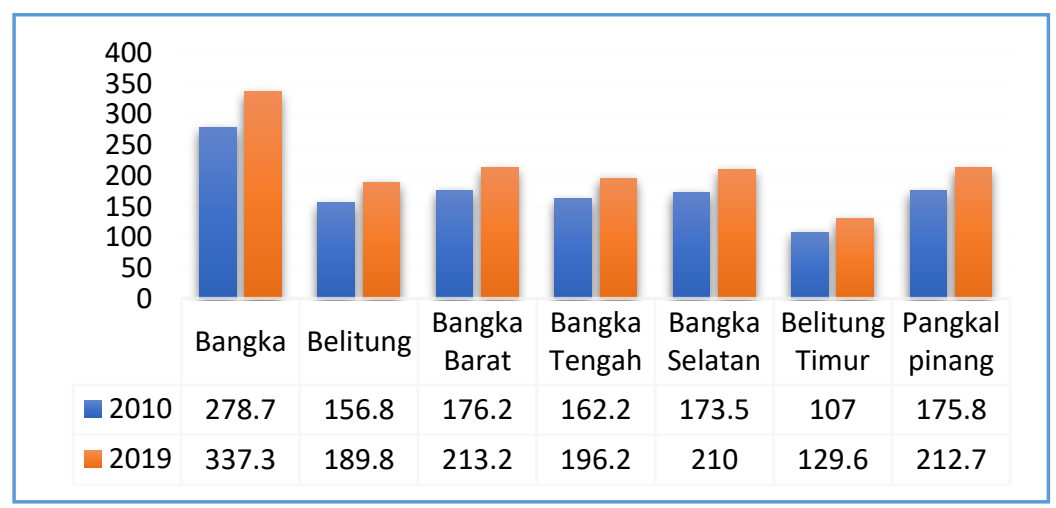

Figure 1. Total Population by Regency/City in the Province of Bangka Belitung Islands Source: Bangka Belitung Islands Province in Figures (2020).

Based on Figure 1. The total population in the Province of Bangka Belitung Islands in 2010 was $1,230.2$ thousand people and it increased in 2019 by 21.02 percent to $1,488.8$ thousand people. The regency/city with the largest population was Bangka Regency with a population of 337.3 thousand people in 2019 and the one with the lowest population was East Belitung Regency with a population of 129.6 thousand people in 2019. 
The high population in Bangka Regency needs to be supported by the region's ability to provide services to the community by building adequate facilities to encourage community economic activities in Bangka Regency. The following is the total population, area, and population density by the district in Bangka Regency.

Table 1. Total Population, Area, and Population Density by District in Bangka Regency in 2019

\begin{tabular}{|r|l|r|r|r|}
\hline & No. & \multicolumn{3}{|c|}{ Region } \\
\hline $\mathbf{1}$ & Sungailiat & $\begin{array}{c}\text { Total Population } \\
\text { (People) }\end{array}$ & $\begin{array}{c}\text { Area } \\
\left(\mathbf{K m}^{2}\right)\end{array}$ & $\begin{array}{c}\text { Population Density } \\
\text { Per Km }\end{array}$ \\
\hline $\mathbf{2}$ & Belinyu & 91.822 & 146.38 & 627.29 \\
\hline $\mathbf{3}$ & Mendo Barat & 49,229 & 546.5 & 90.08 \\
\hline $\mathbf{4}$ & Pemali & 48,853 & 570.46 & 85.64 \\
\hline $\mathbf{5}$ & Merawang & 33,379 & 127.87 & 261.04 \\
\hline $\mathbf{6}$ & Riau Silip & 29,743 & 164.4 & 180.92 \\
\hline $\mathbf{7}$ & Puding Besar & 27,773 & 523.68 & 53.03 \\
\hline $\mathbf{8}$ & Bakam & 19,484 & 383.29 & 50.83 \\
\hline
\end{tabular}

Source: Bangka Regency in Figures (2020).

The district that has the highest population and population density is Sungailiat District with a population of 91,822 people and a population density of 627.29 people per $\mathrm{km}^{2}$. Meanwhile, Bakam District has the lowest population and population density, which is 18,473 people with a population density of 37.85 people per $\mathrm{km}^{2}$.

Bangka Regency has various potentials to be developed in regional development through a growth center approach. From a sectoral approach, the potentials in Bangka Regency include the processing industry, plantations, tourism, trade, and services as well as mining. The contribution of the Gross Regional Domestic Product (GRDP) of the economic sector in Bangka Regency can be seen in Figure 2.

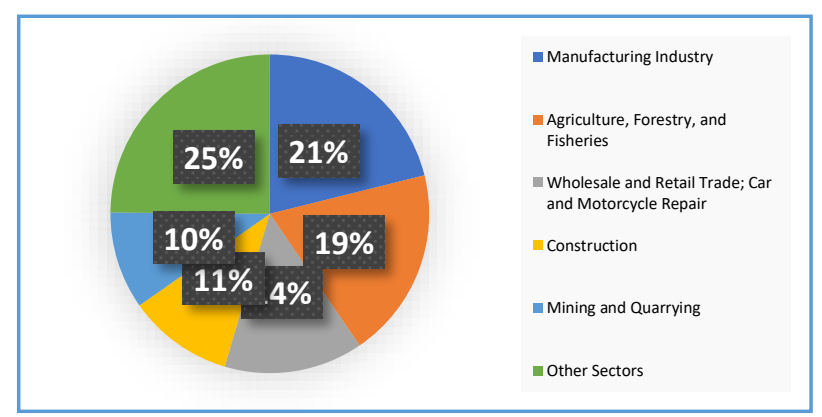

Figure 2. Contribution of Gross Regional Domestic Product in Bangka Regency in 2019 Source: Bangka Regency in Figures, Processed (2020).

The economic structure of Bangka Regency was dominated by 5 (five) business fields in 2019, including: first, the Manufacturing Industry business field by 21.23 percent; second, business fields including Agriculture, Forestry, and Fisheries by 19.46 percent; third, wholesale and retail trade business fields including Car and Motorcycle Repair by 14.17 percent; fourth, construction business fields by 10.73 percent; and fifth, mining and quarrying business fields by 9.94 percent. Meanwhile, 
the remaining 25 percent was contributed by other sectors. This means that each business field has a role in the formation of the GRDP of Bangka Regency (Bangka Regency in Figures, 2020).

In addition to the sectoral approach or economic structure, regional development planning also needs to pay attention to the regional approach. The regional development approach is carried out based on Government Regulation No. 13 of 2017, Amendment to Government Regulation No. 26 of 2008 concerning the National Spatial Planning (RTRWN). The development gap between regions occurs because the concept of development is seen from a sectoral approach. So, the government changed the concept from a sectoral approach to a regional approach (Sun'an \& Senuk, 2015). The regional approach looks at the spatial number of facilities in Bangka Regency to support community activities. The development of Bangka Regency area is indicated by the increase in physical development to serve community activities. The existence of facility arrangements aims to ensure that the facilities provided can be utilized efficiently by the community and are not excessive (wasteful). Also, the community can get the facilities they need without sacrificing more costs, time, and energy because they are far apart (Tarigan, 2019).

The facilities in Bangka Regency include educational facilities, health facilities, economic facilities, and social facilities which are spread across every district in Bangka Regency. The largest distribution of educational facilities, health facilities, and economic facilities is in Sungailiat District with 94 units, 25 units, and 130 units, respectively. Furthermore, the lowest distribution of educational facilities, health facilities, and economic facilities, is in Bakam District with 28 units, 5 units, and 25 units, respectively. Meanwhile, the distribution of social facilities, which are in the form of worship facilities, is the largest in Belinyu District with 112 units and the lowest is in Puding Besar District with 33 units (Bangka Regency in Figures, 2020).

The existence of a gap in facilities owned by each district in Bangka Regency determines the area as a growth center that has the most complete number of facilities or becomes a supporting area (hinterland) with fewer facilities. The selection of districts as growth centers will provide a large multiplier effect, and this is due to the investment spent to build facilities that can be reached by the community at large (Soares et al., 2017). The existence of a growth center will provide a location advantage in the back area, where there is a polarization effect and a trickling down effect in the form of concentration of investment that can increase the attractiveness of the surrounding area (Arsyad, 2016).

The development of public facilities, both government and private ones for each district in Bangka Regency need to be studied further to see how big the center of growth and interaction between districts in Bangka Regency is. Good steps need to be taken to accelerate economic development, namely by establishing growth centers/economic services in the regions and supporting areas (hinterland). Through this growth center, it is hoped that it will provide a spread effect for the regions behind it. Based on this, the researcher is interested in researching with the title "Analysis of the Development of Hinterland Areas and Growth Centers in Bangka Regency". This study aims to (1) prove and analyze that the district is the center of growth and a supporting area (hinterland) in Bangka Regency, (2) some major indices and growth centers centrality support area (hinterland) in Bangka Regency, and (3) how big the interaction strength between growth centers is.

\section{Literature Review \\ Economic Development Theory}

Smith (1776) argued that economic development was a process that combined population growth with technological progress. This means that population growth and technological progress must be balanced (Rochaida, 2016). Economic specialization will occur if population growth is balanced with rapid technological advances (Sukirno, 2011). Economic development can be interpreted as a process that in the long term will lead to an increase in the real income per capita of the population of a country and at the same time will be accompanied by an improvement in the institutional system (Arsyad, 2016). Based on this understanding, development is preceded by an increase in people's income and economic growth in carrying out development. Therefore, the regional government as the 
person in charge of the region must strive to increase the economic growth of the region by maximizing every potential possessed by the region (Nainggolan, 2015).

\section{Growth Pole Theory}

The growth pole theory of economic space was put forward by Francois Perroux. Perroux (1950) stated that the growth pole was related to the relationship and concentration between the company and the industry. Growth will not occur in all regions at the same time, but growth will occur at the growth poles with different intensities and different consequences (Arsyad, 2016). In addition to Perroux, experts who put forward the theory of the growth center are Myrdal (1957), Hirschman (1958), Boudeville (1966), and Friedmann (1972).

Myrdal (1957) revealed that there was a spread effect and a backwash effect for the growth of the back area. The backwash effect, which is stronger than the spread effect, allows the economic absorption of the surrounding area to become the center of growth for the region. If there is no market mechanism intervention policy, economic growth will result in regional growth inequality (Arsyad, 2016). Hirschman (1958) stated that there was a polarization effect and a trickling down effect, which meant that economic growth at the center of growth would affect the area behind it (Arsyad, 2016). Boudeville (1966) suggested the need to choose the location of the center or growth pole to encourage the cumulative effect of economic activity and spread it to the back region to be able to even out economic growth from the center to the back area (Arsyad, 2016). Friedman (1972) stated that development was a process of social and economic integration, where economic growth was influenced by the existence of various innovations in the core area which then spread to the periphery (Arsyad, 2016). Geographically, the growth center is a location that has many facilities and conveniences, so that it becomes a center of attraction (pole of attraction) which attracts various businesses to be located there and people are happy to come to take advantage of the existing facilities at that location. The criteria for a growth center are being a fast-growing area, having a leading sector, and having economic interaction with the region behind it or hinterland (Gulo, 2015).

\section{Gravity Theory}

The theory of gravity can be used by regional planners to estimate the attractiveness of a location compared to other locations in the vicinity based on Newton's law "Two adjacent masses will attract each other and the attraction of each mass is proportional to its weight." It can be seen that a facility built in a certain location will attract enough customers or not. By looking at the location, it can be estimated which facilities need to be built or not or look for a more strategic location (Tarigan, 2019). Facilities are used to meet the needs of the population. The more complete the provision of facilities in a place is, the stronger the attraction for residents from other areas to come to the area to carry out productive activities will be. This area can act as a liaison between the regions with the smallest areas, namely rural areas (Imelda, 2013).

\section{Location Theory}

Losch said that the location of the seller greatly influenced the number of consumers he could work with. If the distance of a market is far from consumers, then consumers will be reluctant to go to buy necessities to the market, and this is due to transportation costs that must be incurred by consumers. So, producers must choose sales locations that are close to consumers to obtain maximum profit by minimizing transportation costs (Tarigan, 2019).

\section{Central Place Theory}

Christaller stated that the central place theory was a theory based on the location and distribution pattern of settlements in space. Christaller's assumption is the same as Lloyd's, where a commodity has a market reach (range) and a minimum market area (threshold) so that those producers can continue to produce (Tarigan, 2019).

So, the market reach for each different commodity is quite wide, medium, and small. The same hierarchy of marketing areas does not overlap, but for different hierarchies, it will overlap. Christaller said that various types of goods in the same order tended to combine at the center of the region so that 
the center became a concentration (city). The city that sells the most complete goods keeps the highest order and the lower the order is, the lower the available goods will be (Tarigan, 2019).

\section{Urban Hierarchy}

The urban hierarchy is related to the hierarchy of public facilities in each city. Public facilities are not only related to the type, but also the capacity and quality of the service. The existence of facility arrangements is intended so that the facilities provided can be used efficiently by the community, the cost of building and maintaining facilities is not excessive (wasted), but the community can be served without sacrificing excessive costs to visit facilities that are far apart. Each city has a supporting area (hinterland), namely several small towns. Cities that have a large influence are given a first-order or rank, and those that have less influence than the first order are given a second-order or rank. Firstorder cities are not subordinated to other cities. Meanwhile, second-order cities are subordinated to first-order cities and third-order cities are subordinated to second-order cities, and so on (Tarigan, 2019).

\section{Hinterland region}

Hinterland is a back area or supporting area whose function is to meet the needs of food or basic materials, such as rice, fruits, corn, and secondary crops. The hinterland area is determined based on the distance between districts and production centers. The function of the city as part of the hinterland region is to function as a growth center and serve sub-regional areas as well as a liaison between big cities and small cities (Ismiwati \& Sayuti, 2019).

\section{Research Methodology}

This research was conducted in Bangka Regency, Bangka Belitung Islands Province. Bangka Regency consists of 8 districts, namely Sungailiat, Merawang, Puding Besar, Bakam, Mendo Barat, Belinyu, Riau Silip, and Pemali Districts.

The research approach in this study is a quantitative descriptive approach. The type of data used is quantitative data in the form of data on the number of educational facilities, health facilities, economic facilities, social facilities, distances between regions, and data on the number of residents in Bangka Regency in 2019. The source of data is secondary data obtained from the publications of Bangka Regency in figures published by the Central Statistics Agency (BPS) of Bangka Regency.

The data collection method in this research is literature study and documentation. The literature study was obtained from previous studies that were relevant to this study. Meanwhile, the documentation method was obtained from the Central Statistics Agency (BPS) of Bangka Regency in Figures of 2020.

The population in this study is the area of Bangka Regency which consists of 8 (eight) districts. The sampling method in this study was saturated sampling. Saturated sampling is a sample that represents the total population where all members of the population are used as samples (Suryani \& Hendryadi, 2015). The sample in this study was 8 (eight) districts in Bangka Regency.

The data analysis methods used are scalogram analysis, centrality index, and gravity analysis. Scalogram analysis is an analytical tool used to determine and see the ability of a region to provide services to the community in an area. The higher the development of a region is, the stronger the region's ability to provide services to the community will be. These services include facilities in areas such as educational, health, economic, and social facilities. The stages of performing a scalogram analysis are as follows:

1) Making a sequence of cities based on the ones with the largest to the smallest population in the table on the left.

2) Creating a sequence of facilities that are determined based on the frequency in the top row.

3) Drawing rows and columns to form a matrix that shows the facilities available in each district area.

4) Using number 0 (zero) to indicate an area that does not have facilities and number 1 (one) to indicate ownership of facilities in an area. 
5) Sorting facilities horizontally and vertically, i.e. sorting facilities column and area column based on the existence of facilities. The facilities with the highest number in an area are at the top. The left column shows the highest number of facilities and the right column shows the lowest number of facilities.

6) Determining the order of each district using the Strugges formula.

Number of orders $=1+(3.3 \log n)$

Where:

$\mathrm{n} \quad=$ Number of Districts

7) Counting the number of ranges in each order

Range $=\frac{\text { Highest number of facilities-Lowest number of facilities }}{\text { Cat }}$

8) Calculating COR (Coefficient of Reducibility) or error rate

The COR calculation formula is as follows:

$\mathrm{COR}=1-\frac{\sum \mathrm{e}}{\mathrm{N} \times \mathrm{K}}$

Where:

$\sum \mathrm{e} \quad=$ Number of Errors

$\mathrm{N} \quad=$ Number of Facilities

$\mathrm{K} \quad \mathrm{s}=$ Number of Districts

If the COR value is between 0.9 and 1 , then the scalogram analysis has a low error rate and deserves to be analyzed.

9) Identify ratings or orders that can be interpreted based on the value of the presence of facilities in an area. The higher the value is, the higher the order will be (Nandya, 2016).

According to Rodinelli (1985), Centrality Index Analysis is an analysis based on the frequency of existence of functions or facilities in an area. The frequency of the existence of the function shows the number of functions of similar facilities scattered in an area (Pratama, 2019).

Calculation of the centrality index is done by using the number of existing facilities and then determining the weight of each facility using the formula:

Where:

$$
\mathrm{C}=\frac{\mathrm{t}}{\mathrm{T}}
$$

$\mathrm{C}=$ centrality index facility weight

$\mathrm{t}=$ centrality value; this analysis uses an index of 100

$\mathrm{T}=$ total number of facilities

According to Tarigan (2019), gravity analysis is an analysis used to find out how much interaction or economic attractiveness the growth center has with its supporting areas or hinterland areas, and then look for areas that have the strongest interactions with other regions and find out the role of the region as a growth center in Bangka Regency. The following formula for gravity analysis is:

$\mathrm{T}_{\mathrm{ij}}=\mathrm{k}\left(\frac{\left(\mathrm{P}_{\mathrm{i}} \times \mathrm{P}_{\mathrm{j}}\right)}{\mathrm{d}_{\mathrm{ij}} \mathrm{b}}\right)$

Where:

$\mathrm{i}=$ district of origin (growth center)

$\mathrm{j}=$ destination district (supporting area (hinterland))

$\mathrm{T}_{\mathrm{ij}}=$ the magnitude of the interaction between region $\mathrm{i}$ and region $\mathrm{j}$

$P_{i}=$ population of district $\mathrm{i}$ (people)

$P_{j}=$ total population of district $j$ (people)

$\mathrm{d}_{\mathrm{ij}}=$ distance between district $\mathrm{i}$ and district $\mathrm{j}$ (kilometers)

$\mathrm{k}=$ number of empirical constants, worth 1

$b=$ power of $d_{i j}$, which is often used is $b=2$

According to Aronoff (1989), the Geographic Information System (GIS) approach is a computerbased information system used to process and store geographic data or information (Sumantri et al., 2019). A Geographic Information System is a spatial analysis technique used to analyze spatial 
studies (Pratama, 2019). The GIS method is used to analyze spatial data in the form of making digital maps to find out and provide convenience where the distribution of facilities and interactions in growth centers and supporting areas (hinterland) in Bangka Regency (Ardani, 2019).

\section{Results and Discussion}

Bangka Regency consists of 8 districts, 62 villages, and 9 sub-districts with the district capital located in Sungailiat district. The area of Bangka Regency is approximately $302,100 \mathrm{Ha}$ or $3,021 \mathrm{Km}^{2}$. It consists of a land area without small islands and the Seven Islands which is $2,950.68 \mathrm{Km}^{2}$ and the rest is an ocean area of $70.32 \mathrm{Km}^{2}$.

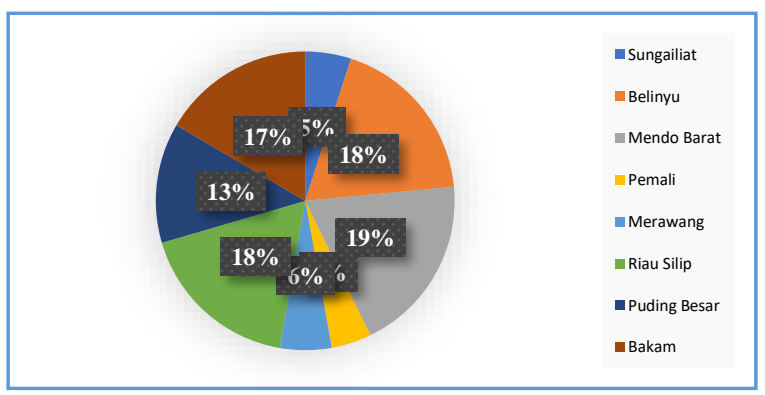

Figure 3. Percentage of Area by District of Bangka Regency Source: Bangka Regency in Figures (2021).

The district that has the most extensive area among the 8 districts in Bangka District is Mendo Barat with an area of $570.46 \mathrm{~km}^{2}\left(19.33\right.$ percent), then Belinyu District with an area of $546.50 \mathrm{Km}^{2}(18.52$ percent), and Riau Silip District with an area of $523.68 \mathrm{Km}^{2}$ (17.75 percent). Meanwhile, the smallest district is the Pemali District Pemali with an area of $127.87 \mathrm{Km}^{2}$ (4.33 percent), then Sungailiat District with an area of $146.38 \mathrm{~km}^{2}$ (4.96 percent), and Merawang District with an area of 164.40 $\mathrm{Km}^{2}$ (5.57 percent).

The total population in Bangka Regency in 2010 was 278,740 people, and in 2019, there were 318,756 people consisting of 163,957 male residents (51.44 percent) and 154,799 female residents (48.56 percent). The population from 2010 to 2019 continued to increase by 14.36 percent. This population growth is not only influenced by the high birth rate (natality) but also due to the higher life expectancy, so that the death rate (mortality) decreases, and the migration factor. The migration factor is quite large due to the development of Bangka Regency area from various economic sectors so that it becomes an attraction to come to Bangka Regency.

In 2019, the district with the largest population was Sungailiat District with 91,822 inhabitants, an increase of 10.45 percent compared to 2010. The average population in Sungailiat District from 2010 to 2019 was 87,478 people with a population density of 627.29 people per $\mathrm{km}^{2}$. A large number of residents in Sungailiat District is because Sungailiat District is the capital of Bangka Regency so that many residents inhabit Sungailiat District and are also supported by available facilities. Meanwhile, Bakam District is the district with the smallest population with an average of 17,609 inhabitants. The total population in Bakam District in 2019 was 18,473 people with a population density of 37.85 people per $\mathrm{km}^{2}$. This is because Bakam District still has a lot of forests and oil palm plantations and Bakam District is not the main crossing route to the district capital so that the population of Bakam District is small.

\section{Scalogram Analysis Result}

Scalogram analysis is used to determine the order of the districts by taking into account the available facilities including educational, health, economic, and social facilities. In total, there are 25 types of facilities that will be used to determine the order of each district. The types of facilities include:

1. Educational facilities consist of TK (Kindergarten), SD/MI (Elementary School), SMP/MTs (Junior High School), SMA/SMK/MA (Senior High School/Vocational High School), and Academy/College/University. 
2. Health facilities consist of hospitals, special hospitals, maternity hospitals, health centers, subhealth centers, integrated healthcare centers, pharmacies, and polyclinics.

3. Economic facilities consist of BUMDes, traditional markets, boat moorings, hotels, banks, cooperatives, ports, and terminals.

4. Social facilities consist of mosques/musholla, churches, pagodas, and monasteries.

The first step is sorting the rows based on the largest population and sorting the columns based on the highest number of types of facilities in each district. Then, the next step is determining the orders of the number of types of facilities with the following calculations:

Formula Order $=1+3.3 \log n$

Where:

$\mathrm{n}=$ Number of Districts

Sum of orders $=1+3.3 \log \mathrm{n}$

Sum of orders $=1+3.3 \log 8$

Sum of orders $=1+3.3(0.9031)$

Number of orders $=1+2.9802$

Number of orders $=\mathbf{3 . 9 8 0 2}$

So, based on the result of the calculation, the number of orders or classes is 3.9802 , which is rounded up to 4 orders for the districts in Bangka Regency. Then, the range or class range with the formula for the highest number of facilities (25) minus the lowest number of facilities (14) divided by the number of orders (4) is 2.75 .

Table 2. Order and Range of Scalogram

\begin{tabular}{|c|l|}
\hline Order & \multicolumn{1}{|c|}{ Range $(\mathbf{2 . 7 5})$} \\
\hline I & 22.28 to 25.03 \\
\hline II & 19.52 to 22.27 \\
\hline III & 16.76 to 19.51 \\
\hline IV & 14 to 16.75 \\
\hline
\end{tabular}

Source: Processed by Researchers (2021)

The following is a scalogram calculation table consisting of 4 orders and the level of error:

Table 3. Determination of the Order Based on the Number of Types of Facilities and the Error Level of Each District in Bangka Regency

\begin{tabular}{|l|l|l|l|l|l|l|l|l|l|l|l|l|l|l|l|l|}
\hline No & Regency & District & $\begin{array}{c}\text { Total } \\
\text { Population } \\
\text { (People) }\end{array}$ & $\begin{array}{c}\text { Area } \\
\left(\mathrm{Km}^{2}\right)\end{array}$ & $\begin{array}{c}\text { Population } \\
\text { Density } \\
\text { Per Km }\end{array}$ & A & B & C & D & I & J & K & N & S & V & O \\
\hline $\mathbf{1}$ & Bangka & Sungailiat & 91,822 & 146.38 & 627.29 & 1 & 1 & 1 & 1 & 1 & 1 & 1 & 1 & 1 & 1 & 1 \\
\hline $\mathbf{2}$ & Bangka & Belinyu & 49,229 & 546.5 & 90.08 & 1 & 1 & 1 & 1 & 1 & 1 & 1 & 1 & 1 & 1 & 1 \\
\hline $\mathbf{3}$ & Bangka & Merawang & 29,743 & 164.4 & 180.92 & 1 & 1 & 1 & 1 & 1 & 1 & 1 & 1 & 1 & 1 & 1 \\
\hline $\mathbf{4}$ & Bangka & Mendo & 48,853 & 570.46 & 85.64 & 1 & 1 & 1 & 1 & 1 & 1 & 1 & 1 & 1 & 1 & 1 \\
\hline $\mathbf{5}$ & Bangka & Pemali & 33,379 & 127.87 & 261.04 & 1 & 1 & 1 & 1 & 1 & 1 & 1 & 1 & 1 & 1 & 1 \\
\hline $\mathbf{6}$ & Bangka & Riau Silip & 27,773 & 523.68 & 53.03 & 1 & 1 & 1 & 1 & 1 & 1 & 1 & 1 & 1 & 1 & 1 \\
\hline $\mathbf{7}$ & Bangka & $\begin{array}{l}\text { Puding } \\
\text { Besar }\end{array}$ & 19,484 & 383.29 & 50.83 & 1 & 1 & 1 & 1 & 1 & 1 & 1 & 1 & 1 & 1 & 1 \\
\hline $\mathbf{8}$ & Bangka & Bakam & 18,473 & 488.1 & 37.85 & 1 & 1 & 1 & 1 & 1 & 1 & 1 & 1 & 1 & 1 & 1 \\
\hline Total & & & & & 8 & 8 & 8 & 8 & 8 & 8 & 8 & 8 & 8 & 8 & 8 \\
\hline
\end{tabular}




\begin{tabular}{|c|c|c|c|c|c|c|c|c|c|c|c|c|c|c|c|c|c|}
\hline \multirow[t]{2}{*}{ No } & District & \multicolumn{16}{|c|}{ Number of Errors } \\
\hline & & $\mathrm{R}$ & W & $\mathrm{X}$ & $\mathrm{L}$ & $\mathrm{P}$ & $\mathrm{Y}$ & $\mathrm{E}$ & $\mathrm{F}$ & M & Q & $\mathrm{T}$ & $\mathrm{U}$ & G & $\mathrm{H}$ & Total & $\begin{array}{l}\text { Number } \\
\text { of errors }\end{array}$ \\
\hline 1 & Sungailiat & 1 & 1 & 1 & 1 & 1 & 1 & 1 & 1 & 1 & 1 & 1 & 1 & 1 & 1 & 25 & 0 \\
\hline 2 & Belinyu & 1 & 1 & 1 & 1 & 1 & 1 & 0 & 1 & 1 & 1 & 1 & 1 & 0 & 0 & 22 & 2 \\
\hline 3 & Merawang & 1 & 1 & 1 & 1 & 1 & 1 & 1 & 1 & 1 & 1 & 0 & 0 & 0 & 0 & 21 & 0 \\
\hline 4 & $\begin{array}{l}\text { Mendo } \\
\text { Barat }\end{array}$ & 1 & 1 & 1 & 1 & 1 & 0 & 1 & 0 & 1 & 1 & 0 & 0 & 0 & 0 & 19 & 4 \\
\hline 5 & Pemali & 1 & 1 & 1 & 1 & 0 & 0 & 1 & 0 & 0 & 0 & 0 & 0 & 0 & 0 & 16 & 2 \\
\hline 6 & Riau Silip & 1 & 1 & 1 & 0 & 1 & 1 & 0 & 0 & 0 & 0 & 0 & 0 & 0 & 0 & 16 & 2 \\
\hline 7 & $\begin{array}{l}\text { Puding } \\
\text { Besar }\end{array}$ & 1 & 0 & 0 & 1 & 1 & 0 & 0 & 1 & 0 & 0 & 0 & 0 & 0 & 0 & 15 & 4 \\
\hline 8 & Bakam & 0 & 1 & 1 & 0 & 0 & 1 & 0 & 0 & 0 & 0 & 0 & 0 & 0 & 0 & 14 & 2 \\
\hline \multicolumn{2}{|c|}{ Total } & 7 & 7 & 7 & 6 & 6 & 5 & 4 & 4 & 4 & 4 & 2 & 2 & 1 & 1 & 148 & 16 \\
\hline
\end{tabular}

Source: Processed by Researchers (2021)

Where:

Educational facilities:

A: TK (Kindergarten)

B: SD/MI (Elementary School)

C: SMP/MTs (Junior High School)

D: SMA/SMK/MA (Senior High

School/Vocational High School)

E: Academy/College/University

\author{
Health facilities: \\ F: Hospitals \\ G: Special Hospitals \\ H: Maternity Hospitals \\ I: Health Centers \\ J: Sub-health Centers \\ K: Integrated Healthcare Center \\ L: Pharmacies \\ M: Polyclinics
}

Economic facilities:

$\mathrm{N}$ : BUMDes

O: Traditional Markets

P: Boat Moorings

Q: Hotels

R: Banks

S: Cooperatives

T: Ports

$\mathrm{U}$ : Terminals

The districts in Bangka Regency are classified in order or hierarchy. The highest number of facilities in one district is 25 types of facilities, while the lowest number is 14 types of facilities with 16 errors. The final step is to calculate the Coefficient of Reducibility (COR) error rate. The following is the COR calculation:

COR formula $=1-\frac{\sum \mathrm{e}}{\mathrm{Nxk}}$

Where:

$\sum \mathrm{e}=$ number of errors

$\mathrm{N}=$ number of facilities

$\mathrm{k}=$ number of districts

$\mathrm{COR}=1-\frac{\sum \mathrm{e}}{\mathrm{Nxk}}$
$\mathrm{COR}=1-\frac{\sum 16}{25 \times 8}$
$\mathbf{C O R}=\mathbf{0 . 9 2 0}$

Based on the calculation results, the COR value is 0.920 , which is between 0.9 and 1 or more than 90 percent, so that the scalogram analysis of the facilities in each district of Bangka Regency is considered feasible.

Table 4. Results of Scalogram Analysis

\begin{tabular}{|l|l|l|l|}
\hline No. & Districts & Number of Facilities & Order \\
\hline $\mathbf{1}$ & Sungailiat & 25 & I \\
\hline $\mathbf{2}$ & Belinyu & 22 & II \\
\hline $\mathbf{3}$ & Merawang & 21 & II \\
\hline $\mathbf{4}$ & Mendo Barat & 19 & III \\
\hline $\mathbf{5}$ & Pemali & 16 & IV \\
\hline $\mathbf{6}$ & Riau Silip & 16 & IV \\
\hline $\mathbf{7}$ & Puding Besar & 15 & IV \\
\hline $\mathbf{8}$ & Bakam & 14 & IV \\
\hline
\end{tabular}

Source: Processed by Researchers, 2021 
The following are the results of the mapping from the scalogram analysis:

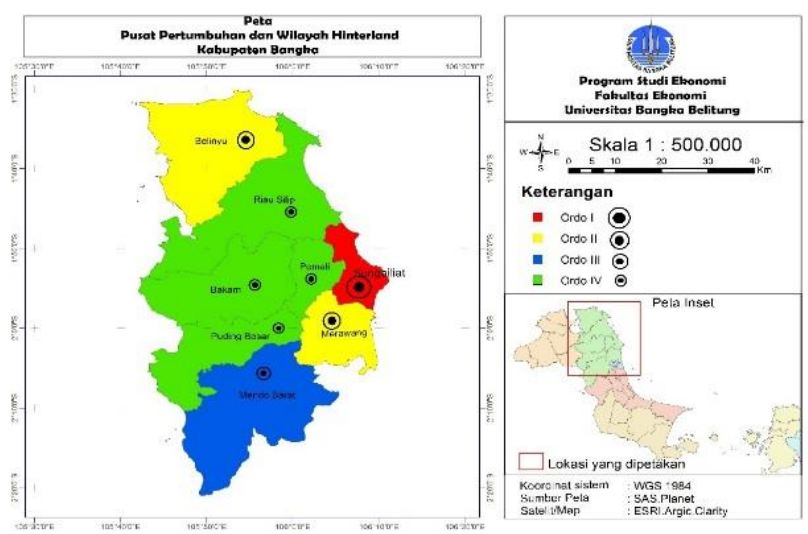

Figure 4. Map of Scalogram Calculation Results Source: Processed by Researchers (2021)

Based on the results of the scalogram analysis, it was found that there were 4 (four) orders in each district in Bangka Regency, namely:

a. Order I is the district with the highest level of facility existence, namely the district which has a total of 25 types of facilities so that the district in Order I is Sungailiat District. So, it is considered as a growth center.

b. Order II is a district that has a high number of facilities, namely districts that have many facilities from 21 to 22 types of facilities so that districts that are in Order II are Belinyu and Merawang Districts.

c. Order III is a district that has a moderate number of facilities, namely a district that has 19 types of facilities so that the district that is in Order III is Mendo Barat District.

d. Order IV is a district that has a low number of facilities, namely districts that have a total of 1416 types of facilities so that districts that are in Order IV are Pemali, Riau Silip, Puding Besar, and Bakam Districts.

\section{Centrality Index Analysis Result}

It is not enough to determine the growth center by considering the number of facilities in each district using scalogram analysis, but it is also necessary to determine the centrality index with the number of facility units in each district, the higher the frequency, the greater the centrality value. Calculation of the centrality index is determined based on the weight of the facility. After calculating the weight of facilities on the centrality index of each district in Bangka Regency, the number of orders on the centrality index is 4 with a range of 209.86 .

The following is the order and range of the centrality index:

Table 5. Order and Range of Centrality Index

\begin{tabular}{|c|l|}
\hline Order & Range (209.86) \\
\hline I & 729.18 to 939.04 \\
\hline II & 519.31 to 729.17 \\
\hline III & 309.44 to 519.30 \\
\hline IV & 99.57 to 309.43 \\
\hline
\end{tabular}

Source: Processed by Researchers (2021)

The following table shows the results of the calculation of the centrality index which consists of 4 orders. 
Table 6. Calculation of Marshall Centrality Index Value for Each District in Bangka Regency

\begin{tabular}{|l|l|l|l|l|} 
No. & Districts & $\begin{array}{c}\text { Total } \\
\text { Population } \\
\text { (People) }\end{array}$ & Total & Order \\
\hline $\mathbf{1}$ & Sungailiat & 91.822 & 939.02 & I \\
\hline $\mathbf{2}$ & Belinyu & 49,229 & 463.93 & III \\
\hline $\mathbf{3}$ & Merawang & 29,743 & 292.41 & IV \\
\hline $\mathbf{4}$ & Mendo Barat & 48,853 & 257.98 & IV \\
\hline $\mathbf{5}$ & Puding Besar & 19,484 & 161.26 & IV \\
\hline $\mathbf{6}$ & Riau Silip & 27,773 & 147.02 & IV \\
\hline $\mathbf{7}$ & Pemali & 33,379 & 140.06 & IV \\
\hline $\mathbf{8}$ & Bakam & 18,473 & 99.57 & IV \\
\hline
\end{tabular}

Source: Processed by Researchers (2021)

The following is a regional mapping based on the calculation of the centrality index:

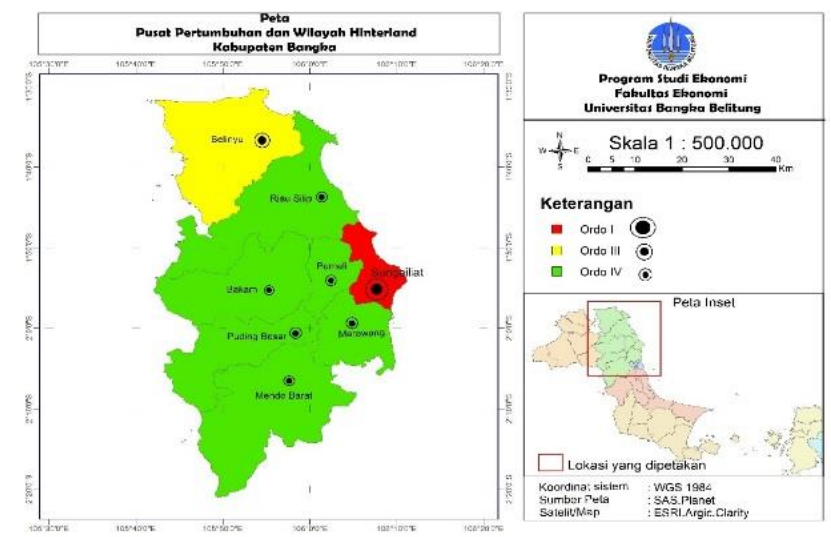

Figure 5. Map of Centrality Index Calculation Results Source: Processed by Researchers (2021)

Based on the results of the Marshall Centrality Index, each district in Bangka Regency has been grouped into 4 (four) orders, namely:

a. Order I is a district with the availability of facilities that has the highest centrality value, namely Sungailiat District with a centrality value of 939.02.

b. Order II is a district with the availability of facilities that has a high centrality value, so that there is no district that is grouped into the second order.

c. Order III is a district with the availability of facilities that has a medium centrality value, namely Belinyu District with a centrality value of 463.93 .

d. Order IV is a district with the availability of facilities that has a low centrality value, namely Merawang District with a centrality value of 292.41, Mendo Barat District with a value of 257.98, Pudding Besar District with a value of 161.26, Riau Silip District with a value of 147.02, Pemali District with a value of 140.06, and Bakam District with a value of 99.57.

Sungailiat District as the center of growth is closely related to the stipulation of this district as the capital of Bangka Regency. Sungailiat District is also the center of government, so that many businesses or community economic activities develop, be it trade and service businesses, small and medium industries as well as the many developments of health, education, economic and social facilities. Sungailiat District has the highest population compared to other districts in 2019, which was recorded at 91,822 people. A large number of residents in this district causes the community's need for the availability of facilities to increase. Therefore, this district functions as a growth center and can provide services to the community and the development of other districts in Bangka Regency. 
Meanwhile, other districts that are in order II to order IV are categorized as hinterland districts or supporting districts. The hinterland districts are Belinyu, Merawang, Mendo Barat, Puding Besar, Riau Silip, Pemali, and Bakam Districts. This is because the value of centrality in these seven districts is below order I. The hinterland districts have a very limited level of availability of facilities. There are four districts, namely Mendo Barat, Pemali, Riau Silip, and Bakam Districts that do not have hospital facilities, and only Puding Besar, Merawang, Belinyu, and Sungailiat Districts that have hospital facilities. Also, none of these seven districts have a maternity hospital. This will reduce health services to the community. It is the same with the economic facilities that have not been spread evenly, such as hotels, banks, ports, and terminals.

\section{Gravity Analysis Results}

The analysis of gravity or interaction in this study is used to see that attractiveness is determined based on the distance and population between districts as growth centers that have the highest scalogram value and centrality index and districts as hinterlands or supporting areas that have orders below the growth center order. A large interaction value means that there is a strong interaction between the growth center and the hinterland (supporting) areas.

Table 7. Gravity Analysis Results of Each District in Bangka Regency

\begin{tabular}{|c|c|c|c|c|c|c|c|}
\hline $\begin{array}{l}\text { Home } \\
\text { District }\end{array}$ & $\begin{array}{l}\text { Destination } \\
\text { District }\end{array}$ & $\begin{array}{l}\text { Resident } \\
\text { of Origin }\end{array}$ & $\begin{array}{c}\text { Destination } \\
\text { Area } \\
\text { Resident }\end{array}$ & $\begin{array}{l}\text { Distance } \\
\mathbf{i}-\mathbf{j} \\
(\mathbf{K m})\end{array}$ & $\begin{array}{c}\text { Distance } \\
(\mathbf{i}-\mathbf{j})^{\mathbf{b}}\end{array}$ & $\begin{array}{c}\text { Interaction } \\
\text { Rate }\end{array}$ & $\begin{array}{l}\text { Interaction } \\
\text { Rating }\end{array}$ \\
\hline (i) & (j) & (Pi) & $(\mathbf{P j})$ & (dij) & $(\mathbf{d i j})^{2}$ & (Aij) & \\
\hline Sungailiat & Pemali & $91,822.00$ & $33,379.00$ & 15 & 225.00 & $13,621,895.72$ & 1 \\
\hline Sungailiat & Merawang & $91,822.00$ & $29,743.00$ & 21 & 441.00 & $6,192,883.78$ & 2 \\
\hline Sungailiat & $\begin{array}{l}\text { Mendo } \\
\text { Barat }\end{array}$ & $91,822.00$ & $48,853.00$ & 33 & 1.089 .00 & $4,119,173.71$ & 3 \\
\hline Sungailiat & $\begin{array}{l}\text { Puding } \\
\text { Besar }\end{array}$ & $91,822.00$ & $19,484.00$ & 32 & 1.024 .00 & $1,747,128.76$ & 4 \\
\hline Sungailiat & Belinyu & $91,822.00$ & $49,229.00$ & 54 & 2.916 .00 & $1,550,173.26$ & 5 \\
\hline Sungailiat & Riau Silip & $91,822.00$ & $27,773.00$ & 42 & 1.764 .00 & $1,445,675.97$ & 6 \\
\hline Sungailiat & Bakam & $91,822.00$ & $18,473.00$ & 38 & 1.444 .00 & $1,174,673.00$ & 7 \\
\hline
\end{tabular}

Source: Processed by Researchers (2021)

The results of the analysis of gravity or interaction mapping are as follows:

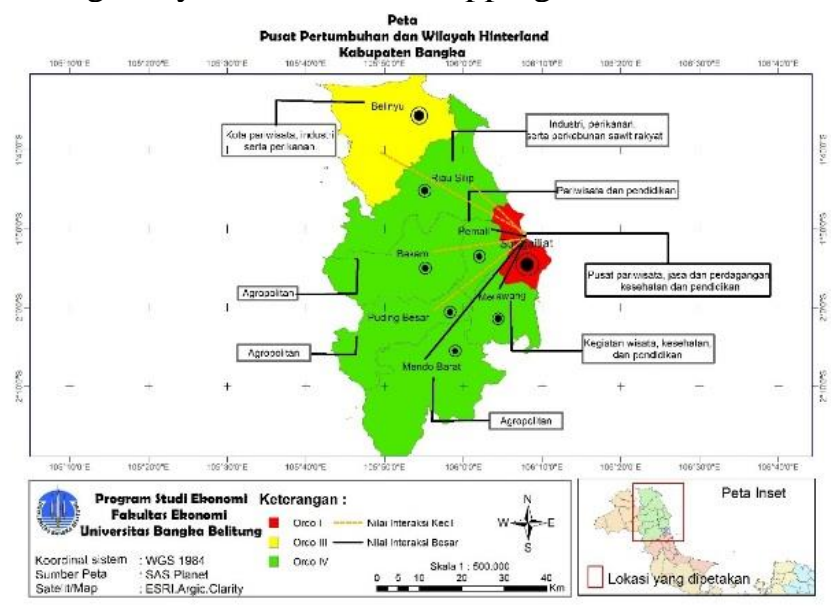

Figure 6. Map of Interaction Results of Each District in Bangka Regency

Source: Processed by Researchers (2021)

The results of the gravity analysis for each district in Bangka Regency are as follows:

a. The highest value of gravity or interaction with Sungailiat District as the center of growth is Pemali District as its hinterland area with an interaction value of $13,621,895.72$. This is because 
Pemali District is the closest district to Sungailiat District with a distance between the districts of approximately $15 \mathrm{Km}$. This means that some of the facilities that are not available in Pemali District allow residents to take advantage of the facilities available in Sungailiat District because of the distance between adjacent districts.

b. Furthermore, the second-highest value of gravity or interaction with Sungailiat District as the center of growth is Merawang District as its hinterland area with an interaction value of 6,192,883.78. In this case, Merawang District is traversed by a primary collector road that connects Pangkalpinang City which functions as a PKW (Regional Activity Center) with Sungailiat and Belinyu Districts as Local Activity Centers (PKL) in which there is a fastgrowing corridor, namely in the Pangkalpinang-Sungailiat corridor. Also, the distance between Sungailiat and Merawang districts is not too far, which is approximately $21 \mathrm{Km}$.

c. Then, the third highest value of gravity or interaction with Sungailiat District as the center of growth is Mendo Barat District as its hinterland area with an interaction value of 4,119,173.71. The distance between Sungailiat District and Mendo Barat District is approximately $33 \mathrm{Km}$.

d. Furthermore, the moderate value of gravity or interaction with Sungailiat District as the center of growth is Puding Besar District as its hinterland area with an interaction value of $1,747,128.76$. This explains the distance between Sungailiat District and Puding Besar District, which is approximately $32 \mathrm{Km}$. Geographically, the strategic location of Puding Besar District, which is at the intersection of Sungailiat District and Pangkalpinang City, makes Puding Besar District have a moderate interaction with Sungailiat District.

e. Furthermore, the moderate value of gravity or interaction with Sungailiat District as the center of growth is Belinyu District as its hinterland area with an interaction value of 1,550,173.26. The distance between Sungailiat District and Belinyu District is approximately $54 \mathrm{Km}$. This distance is the furthest distance between Sungailiat District and other districts in Bangka Regency. Based on the 2010-2030 Regional Spatial Plan, Belinyu District is a Center for Local Activities, and facilities in the health, education, economic, and social fields are quite widespread in this district. So, even though the distance between Sungailiat District as the center of growth and Belinyu District is the farthest of all, it does not make development in Belinyu District backward.

f. Another moderate value of gravity or interaction with Sungailiat District as the center of growth is Riau Silip District as its hinterland area with an interaction value of 1,445,675.97. The distance between Sungailiat District and Riau Silip District is approximately $42 \mathrm{Km}$. This distance is the furthest distance after the distance with Belinyu District. This causes Riau Silip District to have a low interaction value and to be closer to Belinyu District.

g. The weakest value of gravity or interaction with Sungailiat District as the center of growth is Bakam District as its hinterland area with an interaction value of 1,174,673.00. When viewed from the distance between Sungailiat District and Bakam District, it is approximately 38 $\mathrm{Km}$. This low interaction between the districts is because geographically, the villages in Bakam District tend to be around the western area of Bangka Regency, so that residents in Bakam District interact more with West Bangka Regency, especially Kelapa District. The thing that causes the weak interaction between Sungailiat District and Bakam District is because the transportation flow is relatively more crowded and smoother on the main road that connects West Bangka Regency and Pangkalpinang City. This transportation road will make it easier for Bakam people to interact with West Bangka Regency in various activities including economic activities.

Based on the 2010-2030 Regional Spatial Plan (RTRW) in Bangka Regency. The development area of each district in Bangka Regency is classified as Sungailiat and Belinyu Districts as Local Activity 
Centers (PKL). Puding Besar District is classified as a Service Center for Promotional Activities (PKLP). Merawang, Mendo Barat, Bakam, Riau Silip, and Pemali Districts are classified as District Service Centers (PPK). Sungailiat District as a growth center has developed as a center for tourism, services and trade, health, and education. The hinterland districts include Belinyu District as a center for tourism, industries, and fisheries, Merawang District as a center for tourism, health, and education activities, Pemali District as a center for tourism and education, Riau Silip District as a center for industries, fisheries, and smallholders of oil palm plantations. Mendo Barat, Puding Besar, and Bakam Districts are agropolitan areas (Bappeda of Bangka Regency, 2020).

\section{Conclusion}

The district that acts as the center of growth is the district that has the highest order, namely Sungailiat District. Meanwhile, the other seven districts have orders below one, which means that Belinyu District, Merawang District, Mendo Barat District, Pemali District, Riau Silip District, Puding Besar District, and Bakam District are hinterland or supporting areas.

Based on the results of the calculation of the centrality index, it was obtained that Sungailiat District had the highest centrality value of 939.02 being in the first order. Belinyu District had a medium centrality value with a centrality value of 463.93 being in the third order. Meanwhile, other subdistricts had low centrality values, namely Merawang District with a centrality value of 292.41, Mendo Barat District with a centrality value of 257.98, Pudding Besar District with a centrality value of 161.26, Riau Silip District with a centrality value of 147.02, Pemali District with a centrality value of 140.06, and Bakam District with a centrality value of 99.57, all of which are in the fourth-order.

The highest or strongest value of gravity or interaction with Sungailiat District as the center of growth is Pemali District with an interaction value of 13,621,895.72. Furthermore, the second-highest value of gravity or interaction is Merawang District with an interaction value of 6,192,883.78. Furthermore, the third highest value of gravity or interaction is Mendo Barat District with an interaction value of 4,119,173.71. Furthermore, the moderate value of gravity or interaction includes Puding Besar District with an interaction value of $1,747,128.76$, Belinyu District with an interaction value of 1,550,173.26, and Riau Silip District with an interaction value of 1,445,675.97. The weakest value of gravity or interaction is Bakam District with an interaction value of 1,174,673.00.

Based on the mapping of the level of distribution of facilities, Sungailiat District as a growth center has developed as a center for tourism, services and trade, health, and education. The hinterland districts include Belinyu District as a center for tourism, industries, and fisheries, Merawang District as a center for tourism, health, and education activities, Pemali District as a center for tourism and education, Riau Silip District as a center for industries, fisheries, and smallholders of oil palm plantations, and Mendo Barat, Puding Besar, and Bakam Districts as agropolitan areas.

\section{Recommendations}

The suggestions in this study are that the results of the study explain from the results of the calculation of the scalogram and the centrality index that Sungailiat District is designated as a growth center and seven other districts as hinterland areas, the government must pay attention to the distribution of incomplete facilities such as health, education, economic, and social facilities to reduce inequality and accelerate regional development, especially in Bakam District. Bakam District has fewer facilities, namely health facilities in the form of hospitals, maternity hospitals, pharmacies, and polyclinics as well as economic facilities in the form of hotels and banks. Improvement efforts that can be done by the local government are to improve services through the provision and development of facilities and infrastructure. In addition, the need for the development of land transport infrastructure and facilities that support the smooth running of economic activities such as road networks and transportation facilities that can grow and increase interaction or movement of people, goods, and services between the growth center districts and the hinterland areas must be fulfilled, so that the district economic activities that have not experienced growth will also experience growth. 


\section{Acknowledgment}

Thank you very much to the thesis supervisor, Mrs. Dr. Devi Valeriani, S.E., M.Si. and Mrs. Anggraeni Yunita, S.E., M.Si. for their guidance and direction, so that this thesis can be published as an article.

\section{References}

. (2020). Kecamatan Bakam Dalam Angka Tahun 2020. Kabupaten Bangka.

. (2020). Kecamatan Belinyu Dalam Angka Tahun 2020. Kabupaten Bangka.

. (2020). Kecamatan Mendo Barat Dalam Angka Tahun 2020. Kabupaten Bangka.

. (2020). Kecamatan Merawang Dalam Angka Tahun 2020. Kabupaten Bangka.

. (2020). Kecamatan Pemali Dalam Angka Tahun 2020. Kabupaten Bangka.

. (2020). Kecamatan Puding Besar Dalam Angka Tahun 2020. Kabupaten Bangka.

. (2020). Kecamatan Riau Silip Dalam Angka Tahun 2020. Kabupaten Bangka.

. (2020). Kecamatan Sungailiat Dalam Angka Tahun 2020. Kabupaten Bangka.

Ardani, N. (2019). Sistem Informasi Geografis (SIG) untuk Pemetaan Pusat-Pusat Pertumbuhan Wilayah di Kabupaten Temanggung. Naskah Publikasi. Universitas Negeri Semarang.

Ardila, R. (2012). Analisis Pengembangan Pusat Pertumbuhan Ekonomi Di Kabupaten Banjarnegara. Economics Development Analysis Journal, 2(4), 446-455. https://doi.org/10.15294/edaj.vli2.482

Aronoff, S. (1989). Geographic Information Systems: A Management Perspective. Ottawa Canada: WDL Publication.

Arsyad, L. (2016). Pengantar Perencanaan Pembangunan Ekonomi Daerah Edisi Ketiga. Yogyakarta: BPFE-Yogyakarta.

Bappeda Kabupaten Bangka. (2020). Rencana Kerja Pemerintah Daerah Perubahan Kabupaten Bangka. Kabupaten Bangka Tahun 2010-2030.

Boudeville, J. (1966). Problem of Regional Economic Planning. Jerman: Edinburgh U.P

BPS Kabupaten Bangka. (2020). Kabupaten Bangka Dalam Angka Tahun 2020. Kabupaten Bangka.

BPS Provinsi Kepulauan Bangka Belitung. (2020). Provinsi Kepulauan Bangka Belitung Dalam Angka Tahun 2020. Pangkalpinang.

Friedman, J. (1972). Growth Centre in Regional Economic Development. New York: The Free press.

Gulo, Y. (2015). Identifikasi Pusat-Pusat Pertumbuhan dan Wilayah Pendukungnya dalam Pengembangan Wilayah Kabupaten Nias. Widyariset, 18(1), 37-48.

Hirschman, A.O. (1958). The Strategy of Economic Development. New Haven: Yale University Press.

Imelda. (2013). Identifikasi Pusat Pertumbuhan dan Daerah Hinterland Kota Palembang. Jurnal Ekonomi Pembangunan, 11(1), 54-66.https://doi.org/10.29259/jep.v11i1.4913

Ismiwati, B., \& Sayuti, M. (2019). Penentuan Pusat Pusat Pertumbuhan dan Wilayah Pendukungnya Sebagai Upaya Pengembangan Wilayah di Kabupaten Lombok Barat, Nusa Tenggara Barat. Jurnal Kompetitif: Media Informasi Ekonomi Pembangunan, Manajemen Dan Akuntansi, 5(2), 69-82.

Kuncoro, M. (2018). Perencanaan Pembangunan Daerah Teori dan Aplikasi. Jakarta: PT Gramedia Pustaka Utama.

Myrdal. (1957). Economic Theory and Underdeveloped Region. London: Allen and Unwin.

Nainggolan, P. (2015). Analisis Penentuan Pusat-Pusat Pertumbuhan Ekonomi Di Kabupaten Simalungun. Jurnal Ekonomi Dan Keuangan, 1(12), 14770. https://doi.org/10.31227/osf.io/gq235

Nandya, A.F. (2016). Identifikasi Pusat Pertumbuhan dan Wilayah Hinterland di Kabupaten Sleman. Naskah Publikasi. Universitas Islam Indonesia.

Perroux, F. (1950). Economic Space, Theory and Application. Quarterly Journal of Economics, Vol. 64

Pratama, R. (2013). Penentuan Pusat Pertumbuhan Dan Pelayanan Publik Di Kabupaten Kediri. Skripsi. Program Studi Ekonomi Pembangunan Universitas Jember. 1-82.

Rochaida, E. (2016). Dampak Pertumbuhan Penduduk Terhadap Pertumbuhan Ekonomi dan Keluarga Sejahtera di Provinsi Kalimantan Timur. Forum Ekonomi, 18(1), 14-24.

Rodinelli, A.D. (1985). Applied Methods of Regional Analysis: The Spatial Dimensions of Development Policy. Bolder and London: Westview Press.

Smith, A. (1776). An Inquiry Into the Nature of Causesof the Wealth of Nations dalam Sukirno (2011). Makro Ekonomi Teori Pengantar Edisi Ketiga. Jakarta: Rajawali Pers. 
Soares, L., Rustiadi, E., \& Mulatsih, S. (2017). Analisis Disparitas dan Interaksi Spasial di TimorLeste. Journal of Regional and Rural Development Planning (Jurnal Perencanaan Pembangunan Wilayah Dan Perdesaan), 1(1), 74-86. https://doi.org/10.29244/jp2wd.2017.1.1.74-86

Sukirno, S. (2011). Makro Ekonomi Teori Pengantar Edisi Ketiga. Jakarta: Rajawali Pers.

Sumantri, S.H., Makmur, S., Sobar. S., \& I. D.K.K.W. (2019). Sistem Informasi Geografis (Geographic Information System) Kerentanan Bencana. Jakarta: CV. Makmur Cahaya Ilmu.

Sun'an, M., \& Senuk, A. (2015). Ekonomi Pembangunan Daerah. Jakarta: Penerbit Mitra Wacana Media.

Tarigan, R. (2019). Perencanaan Pembangunan Wilayah Edisi Revisi: Cetakan Kesembilan. Jakarta: PT Bumi Aksara.

Todaro, M.P., \& Stephen, C.S. (2006). Pembangunan Ekonomi Edisi Kesembilan. Jakarta: Penerbit Erlangga.

Utari, M. E. S. (2015). Analisis Sistem Pusat Pelayanan Permukiman Di Kota Yogyakarta Tahun 2014. Journal of Ecomomics and Policy JEJAK, 8(1). https://doi.org/10.15294/jejak.v8i1.3856 